\title{
PREVALENCE OF GASTROINTESTINAL PARASITES IN HORSES IN LUXOR, EGYPT
}

\author{
LAMIAA M. ABD EL-RADY ${ }^{1}$; AHMED K. DYAB ${ }^{2}$; SALWA MAHMOUD \\ ABD-ELRAHMAN ${ }^{3}$ AND SARA A. MOHAMED ${ }^{3}$ \\ ${ }^{1}$ Private Veterinary Clinic, Faculty of Medicine, Assiut University, Egypt \\ ${ }^{2}$ Department of Medical Parasitology, Faculty of Medicine, Assiut University, Egypt \\ ${ }^{3}$ Department of Parasitology, Faculty of Veterinary Medicine Assiut University
}

Received: 5 September 2021; Accepted: 20 September 2021

\begin{abstract}
Gastrointestinal parasites have a direct effect on the health of equines. This study was conducted to determine the prevalence and significance of gastrointestinal parasites of naturally infected horses in Luxor Governorate, Egypt. A total of 100 horse fecal samples were collected during the period from March - 2020 to February -2021 from different ages, sexes and stables. All of these samples were examined by different fecal examination techniques including (direct wet mount, sedimentation and flotation techniques). The present study investigate that the total prevalence of infected horses was $15 \%$. There is a relationship between the GIT infection and the age of the horse. The highest percent of infection was recorded by Strongylus vulgaris $9 \%$ followed by Parascaris equorum 5\%, while the percent of infection by Balantidium coli was $1 \%$ in infected horses. It consequence that horses are highly susceptible to Strongylus irrespective of gender and age or even deworming. Control measures should be put in consideration to totally overcome the parasitic infection.
\end{abstract}

Keywords: Gastrointestinal parasites, Parascaris equorum, Strongylus vulgaris, Balantidium coli.

\section{INTRODUCTION}

Gastrointestinal parasites infect several species of equines, including protozoa, helminthes and gastric

Corresponding author: Ahmed K. Dyab E-mail address: ahmed2015@aun.edu.eg Present address: Department of Medical Parasitology, Faculty of Medicine, Assiut University, Egypt maggots of some species of flies; have been associated with ill thrift, reduced growth rates with colic and poor performance (Tatz et al., 2012). Also, larval cyathostominosis, which is, characterized by diarrhoea, hypoproteinaemia and rapid emaciation, is a critical disease in young grazing horses (Love et al., 1999). The outcome of periodic use of anthelmintic to monitor gastrointestinal 
parasites is the development of anthelmintic resistance and reduced efficacy of available anthelmintic classes (Kaplan et al., 2004; Smith et al., 2015). Several reports in Americas and Europe discuss the resistance of strongyle to Benzimidazole and tetrahydropyrimidines (Peregrine et al., 2014).

It has been reported that macrocyclic lactones (ML) treatment is followed by Shortened egg reappearance period (ERP) (Daniels et al., 2016 and Rossano et al., 2010) and that is an early indicator of strongyle resistance species. Parascaris equorum resistance to macrocyclic lactones also reported in several countries (Peregrine et al., 2014). Such reports focus on the need for controlling the anthelmintic drug usage, to stop the anthelmintic resistance species (Nielsen et al., 2018). (FEC) must be done before treatment to reduce anthelmintic resistance species, and limiting the anthelmintic usage and selective pressure on parasitic infected one (Kaplan et al., 2010). However, the prevalence of infection and anthelmintic resistance in equid population in continuous increasing, because the practice of (FEC) testing couldn't be performed in many working equid populations.

The working horses in Egypt are managed separately with no access to pasture grazing (Salem et al., 2017), therefore, it was hypothesized that the strongyle infection prevalence in this working population of horse could be less based on reports from other countries (Ramey et al., 2020; Nielsen et al., 2018). Furthermore, the information about the doramectin efficacy in equines is limited (Matthee, 2003), despite its common use between equid population (Salem et al., 2017).

The objectives of the current study were to quantify the gastrointestinal parasites burden in working and riding horses in Luxor, Egypt, In order to highlight the factors associated with the severity of gastrointestinal (GI) parasites and perfect treatment and prevention of it.

\section{MATERIALS AND METHODS}

A total of 100 horse fecal samples were collected from different ages, sexes and stables, from animal care hospital in Luxor, Egypt. The samples were collected during the period from March2020 to February -2021. It was collected directly from the rectum, in clean plastic containers $(100 \mathrm{ml}$ size $)$ with $10 \%$ formalin and mixed well and tightly closed then labeled with all information for the animal and breeder included age, sex, and color and general parameters, then the samples were transported in ice box to the parasitology department at faculty of Veterinary Medicine Assiut University. After that, a portion of stool was examined at field by direct wet mount, sedimentation and flotation techniques to identify the gastrointestinal parasites.

\section{ETHICAL ANIMAL RESEARCH}

Ethical approval for the study was granted by Animal Care Hospital and Faculty of Veterinary Medicine, Assiut University. 


\section{Statistical analysis}

The collected data was revised, coded, tabulated, and introduced to a PC using Microsoft Excel. All statistical analysis was done using Stata 14. Data analysis was done for each parameter according to the type of data obtained.

\section{RESULTS}

Table 1: Baseline characteristics
We included 100 Horses from Luxor in this cross-sectional study, demographics data are present in (Table 1), 63 were males, 28 were females and 9 were Foals. The mean age was 3.3 years. Out of the 100 included horses, there were 16 of them infected, 15 with gastrointestinal parasites (Fig.1), the infected horses presented with different signs as shown in (Fig.2).

\begin{tabular}{|c|c|c|c|}
\hline \multirow[b]{2}{*}{ Age } & & $\mathrm{N}=100$ & $\begin{array}{c}\text { Mean age (SD) years } \\
{[\text { Min- Max] }}\end{array}$ \\
\hline & & 100 & $\begin{array}{l}3.3(1.4) \\
{[0.75-8]}\end{array}$ \\
\hline \multirow{3}{*}{ Gender } & Male & 63 & $\begin{array}{c}3.57(1.27) \\
{[1.5-8]}\end{array}$ \\
\hline & Female & 28 & $\begin{array}{c}3.5(1.26) \\
{[2-6]}\end{array}$ \\
\hline & Foal & 9 & $\begin{array}{c}0.95(0.1) \\
0.75-1\end{array}$ \\
\hline \multirow{2}{*}{$\begin{array}{l}\text { Horses } \\
\text { infection }\end{array}$} & Infected & 16 & $\begin{array}{l}2.5(1.39) \\
{[0.83-5]}\end{array}$ \\
\hline & GIT parasite & 15 & $\begin{array}{c}2.45(1.42) \\
{[0.83-5]}\end{array}$ \\
\hline
\end{tabular}



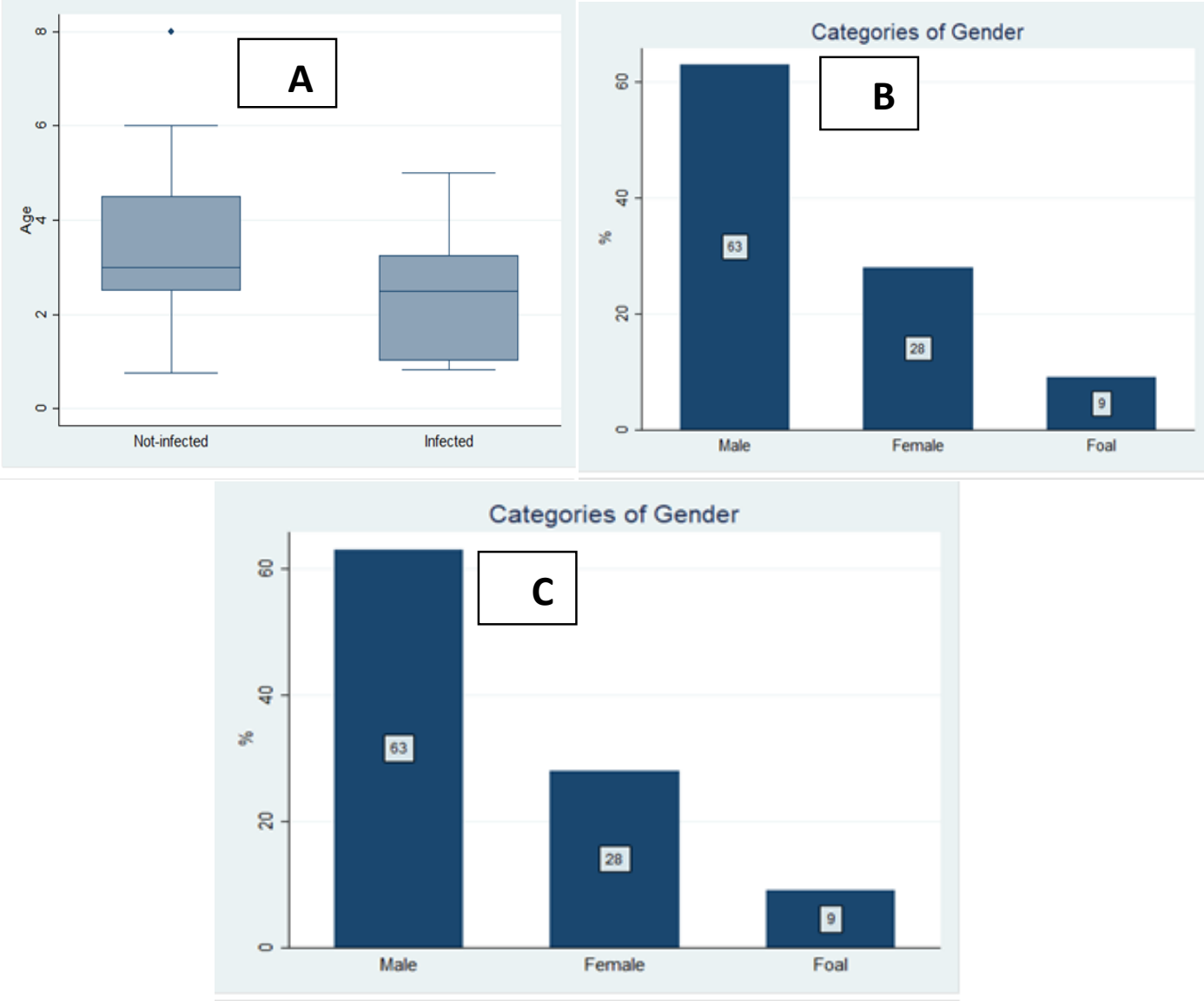

Fig. (1): Demographic characters of studied cases, A: The infected and non-infected cases B: The sex distribution, C: The distribution of different infection.

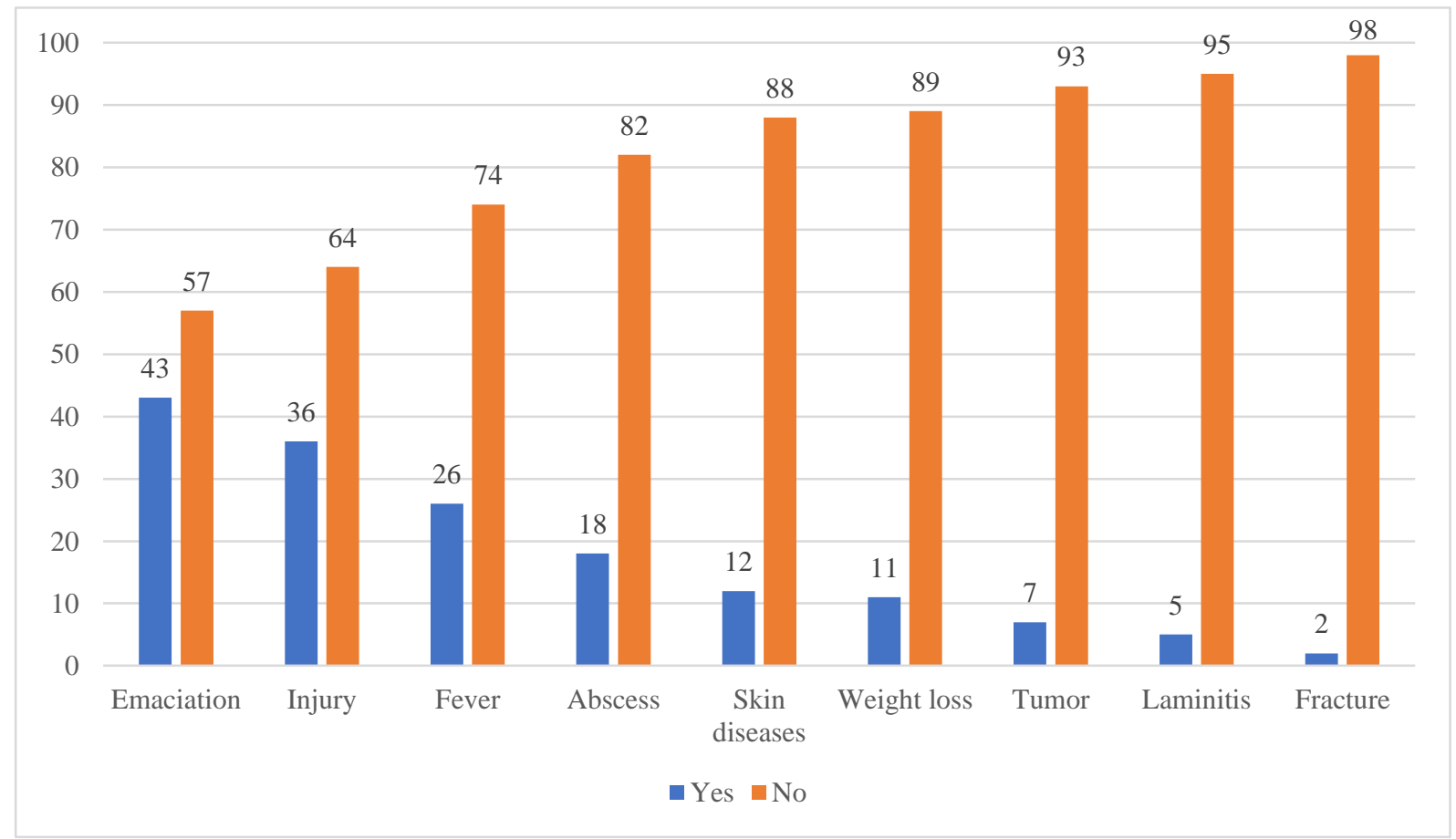

Fig. (2): Symptoms of the included horses 
The prevalence of parasitic infection of horses in Luxor was 16\% [95\% CI 9-25] (Table 2), the main infection is GIT infection with $15 \%$ the prevalence of each GIT parasite subtype in (Table 3) and (Fig.4). Also, there is a relationship between the GIT infection and the age of the horse as shown in (Table 4).

Table 2: Prevalence of Parasitic infection in Horses.

\begin{tabular}{cc}
\hline & Prevalence [95\% CI] \\
\cline { 2 - 2 } Parasitic infection & $16 \%$ \\
& {$[9-25]$} \\
\hline GIT infection & $15 \%$ \\
& {$[7-24]$} \\
\hline
\end{tabular}

Table 3: Prevalence of GIT infection in Horses.

\begin{tabular}{cc}
\hline Parasite & Prevalence [95\% CI] \\
\hline Strongylus vulgaris & $9 \%$ \\
& {$[4.2-16.4]$} \\
\hline Parascaris eqourum & $5 \%$ \\
Balantidium coli & {$[1.6-11.3]$} \\
\hline
\end{tabular}

Table 4: Relationship between the GIT infection and the age of the horses.

\begin{tabular}{|c|c|c|c|c|}
\hline & \multirow{2}{*}{$\begin{array}{c}\text { Mean Difference } \\
\text { Years }\end{array}$} & \multicolumn{2}{|c|}{ 95\% Confidence Interval } & \multirow[t]{2}{*}{ p-value } \\
\hline & & Lower & Upper & \\
\hline Age & 0.96431 & 0.24 & 1.69 & $<0.01$ \\
\hline
\end{tabular}

There was high statistically difference between the age of the infected group and non-infected group using independent t-test, Mean difference $=1$ year [95\% CI 0.24- 1.69], p-value $<0.01$. 

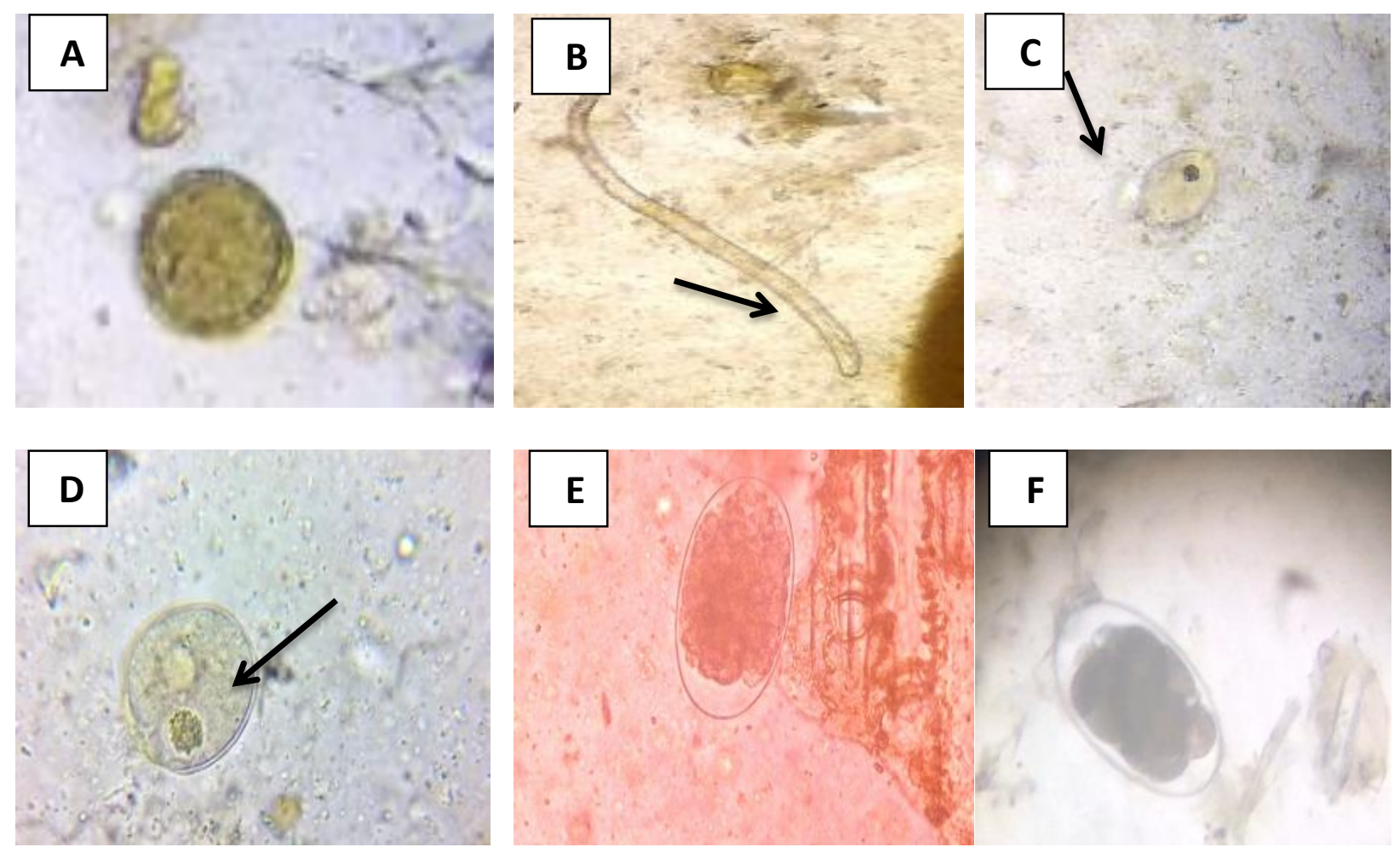

Fig. (3): Different parasitic infection in examined cases, A: Parascaris equorum $\times 200$, B: Nematode larva $\times 200, C \&$ D: Ciliated protozoan parasite trophozoite (Arrow) $\times 400$, E\&F: Strongylus spp. eggs X100.

\section{DISCUSSION}

From the previously mentioned results, three types of gastrointestinal parasites were recorded in horses in animal care in luxor governate during the period from march, 2020 till Feberuary, 2021 as follows discussion:

\section{1- The infection rate of Strongyus vulguris in examined horses:}

In this study, the occurrence of Strongylus vulguris was reported $9 \%$ among 100 examined horse at animal care hospital in Luxor Governorate, from detailed records of examined horse. The occurrence of Strongylus vulguris obtained in this study was lower than those reported by (Shebl et al., 2020) in Egypt, who recorded that, the prevalence of low, medium and high strongyle infection was $(88.4 \%)$ and $(21.14 \%)$ in Dhamar Governorate, Yemen (Alshaibani, Aldalali, \& Alshaibani, 2019) and (99\%)in Ethiopia (Abdurezak et al., 2015).

\section{2- The infection rate of Parascaris equorum in examined horses:}

In this study, the occurrence of Parascaris equorum was reported 5\% among 100 examined horse at animal care hospital in Luxor Governorate, from detailed records of examined horses. This result was in slightly agreement with those reported by (Shebl et al., 2020) (5.1\%) in Egypt. While this finding is considered higher than that previously recorded by (Hinney et al., 2011) (3\%) prevalence of Parascaris 
equorum based on faecal examination in horses of different types in Germany.

On the contrary, the occurrence of Parascaris equorum obtained in this study was lower than those reported by (Othman and Alzuheir, 2019) who recorded that the overall prevalence rate of Parascaris equorum was found to be $15.6 \%$ in native horses in West Bank Palestine and (umar et al., 2013) in naigeria who recorded $(6.3 \%)$ infection rate by parascaris equorum.

\section{3-The infection rate of Balantidium coli in examined horses:}

In this study, the occurrence of Balantidium coli was reported $1 \%$. The occurrence of Balantidium coli obtained in this study was lower than those reported by (Attia et al., 2018).

The reason for the low prevalence of parascaris equorum, strongylus and balantidium in indigenous ones in this study might be relatively to good management system and environmental hygiene, applied in breeding system in Egypt. Another reason for the presence of regular good deworming programme applied in luxor governorate.

\section{REFERANCES}

Abdurezak, M.; Haimanot, D.; Tadele, K.; Tilahun, Z. and Girma, K. (2015): Wollega University, School of Veterinary Medicine, Nekemte, Ethiopia, 7(8): 45-54.

Alshaibani, I.; Aldalali, Z. and Alshaibani, I. (2019):

Epidemiological Study on Gastrointestinal Nematodes of Donkeys in Dhamar Governorate
Yemen.

https://doi.org/10.21276/sjmps.201 9.5.5.5

Attia, M.M.; Khalifa, M.M. and Atwa, M.T. (2018): The prevalence and intensity of external and internal parasites in working donkeys (Equus asinus) in Egypt. Veterinary World, 11(9), 12981306.

Daniels, S.P. and Proudman, C.J. (2016): $\quad$ Shortened egg reappearance after ivermectin or moxidectin use in horses in the UK. Vet J.; 218: 36-9.

Hinney, B.; Wirtherle, N.C.; Kyule, M.; Miethe, N.; Zessin, K.H. and Clausen, P.H. (2011): Prevalence of helminths in horses in the state of Brandenburg, Germany. Parasitol Res; 108(5): 1083-91. doi: 10.1007/s00436-011-2362-z.

Kaplan, R.M.; Klei, T.R.; Lyons, E.T.; Lester, G.; Courtney, C.H. and French, D.D. (2004): Prevalence of anthelmintic resistant cyathostomes on horse farms. J. Am. Vet. Med. Assoc.; 225: 903.

Kaplan, RM. and Nielsen, MK. (2010): An evidence-based approach to equine parasite control: it ain't the 60s anymore. Equine Vet. Educ.; 22: $306-1$

Love, S.; Murphy, D. and Mellor, D. (1999): Pathogenicity of cyathostome infection. Vet Parasitol. 85: 113.

Matthee, S. (2003): Anthelmintic treatment in horses: the extra-label use of products and the danger of under-dosing. J S Afr Vet. Assoc.; 74: 53. 
Nielsen, M.K.; Branan, M.A.; Wiedenheft, A.M.; Digianantonio, R.; Scare, J.A. and Bellaw, J.L. (2018): Risk factors associated with strongylid egg count prevalence and abundance in the United States equine population. Vet Parasitol.; 257 :58-68.

Othman, R. and Alzuheir, I. (2019): Prevalence of Parascaris equorum in native horses in West Bank Palestine. Iraqi Journal of Veterinary Sciences, 33(2), 433436.

https://doi.org/10.33899/ijvs.2019. 163192

Peregrine, A.S.; Molento, M.B.; Kaplan, R.M. and Nielsen, M.K. (2014): Anthelmintic resistance in important parasites of horses: does it really matter? Vet Parasitol.; 201: 1-8.

Prokulewicz, A.; Pilarczyk, B. and Tomza-Marciniak, A. (2014): Evaluation of the efficacy of doramectin in the control of strongyle (Strongylidae, Cyathostominae) infection in horses. Israel J. Vet. Med.; 69: 83.

Ramey, D.W. and Nielsen, M.K. (2020): Limited strongyle parasite occurrence in horses kept in an arid environment. Equine Vet. Educ.;32:S11:37-40. https://doi.org/10.1111/eve.13192.

Rossano, M.G.; Smith, A.R. and Lyons, E.T. (2010): Shortened strongyletype egg reappearance periods in naturally infected horses treated with moxidectin and failure of a larvicidal dose of fenbendazole to reduce fecal egg counts. Vet. Parasitol.; 173: 349-52.

Salem, S.E.; Scantlebury, C.E.; Ezzat, E.; Abdelaal, A.M. and Archer, D.C. (2017): Colic in a working horse population in Egypt: prevalence and risk factors. Equine Vet. J.; 49: 201-6.

Shebl, E.S. (2020): Department of Surgery, Faculty of Veterinary Medicine, Zagazig University, Zagazig 44519, Egypt https://orcid.org/0000-0001-53158934, DOI: $10.1111 /$ evj.13325.

Smith, M.A.; Nolan, T.J.; Rieger, R.; Aceto, H.; Levine, D.G. and NolenWalston, R. (2015): Efficacy of major anthelmintics for reduction of fecal shedding of strongyle-type eggs in horses in the Mid-Atlantic region of the United States. Vet Parasitol.; 214: 139-43.

Tatz, A.J.; Segev, G.; Steinman, A.; Berlin, D.; Milgram, J. and Kelmer, G. (2012): Surgical treatment for acute small intestinal obstruction caused by Parascaris equorum infection in 15 horses (2002-2011). Equine Vet. J.; 44 (Suppl 43): 111-4.

Umar, Y.A.; Maikaje, D.B.; Garba, U.M. and Alhassan, M.A.F. (2013): Department of Biological sciences, Nigerian Defence Academy, Kaduna, Nigeria, J. Vet. Adv., 3(2):43-48, DOI: 10.5455/jva.20130219032443. 


\section{بعض الاراسات على طفيليات الجهاز الهضمى فى الخيول فى الأقصر، مصر

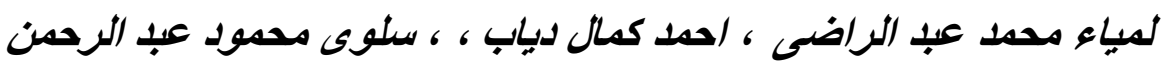

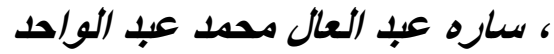

\section{E-mail: ahmed2015@aun.edu.eg Assiut University web-site: www.aun.edu.eg}

أجريت هذه الدراسة لتحديد أهمية طفيليات الجهاز الهضمي ومدى انتشارها بين الخيول في مدينة الأقصر بمصر. وتم جمع مجموعه ... 1 عينة براز من احصنه في مختلف الأعمار والأجناس و الإسطبلات. وجمعت كل هذه العينات خلال

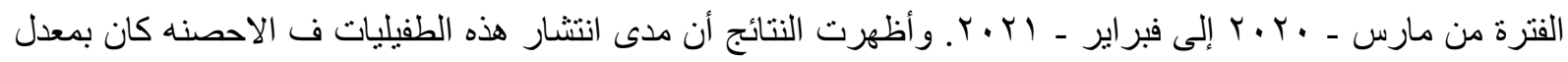
10\%. وكانت نسبه Strongylus vulgaris ف الاحصنه المصابه تصل الى 9\% بينما كانت نسبه الاسكارس 0\% و اخيرا تم ايجاد نسبه و\% اصابه بطفيل Balantidium coli. و هذه النسب تعتبر الى حدا ما ضئيله مقارنه بالابحاث الاخرى. و هذا يشير الى ان نظام الإدارة والنظافة البيئية المطبقة في نظام التربية في مصر جيده الى حد كبير ـ وايضا لوجود برنامج منتظم جيد للتخلص من الديدان المطبق في محافظة الأقصر. 